\title{
Psidium guajava leaves decrease arthritic symptoms in adjuvant-induced arthritic rats
}

\author{
Hanif Nasiatul Baroroh*, Esti Dyah Utami*, and Anisyah Achmad**
}

\section{ABSTRACT}

\section{BACKGROUND}

Guava is an herbal with proven antioxidant and anti-inflammatory properties. The aim of this study was to investigate the anti-arthritic activity of the ethanol extract of Psidium gujava leaves (EEPG) against complete Freund's adjuvant (CFA) induced arthritis in rats.

\section{METHODS}

An experimental study was conducted on 40 male Wistar Sprague Dawley rats, which were divided into 5 groups. Each group was induced with 0.2 $\mathrm{mL} \mathrm{CFA}(1 \mathrm{mg} / \mathrm{mL})$ on day 1 and 0.1 CFA $\mathrm{mL}$ booster injection on day 5 . Group I served as an arthritic control, group II received dexamethasone (6.75 mg.kg-1 orally), group III, IV and V received EEPG at oral doses of 250,500 , and $750 \mathrm{mg} / \mathrm{kg} \mathrm{BW}$, respectively, on days 14 to 28 . Antiarthritic activity was observed from the arthritis score, the paw circumference was measured on days $0,1,4,8,12,16,20,24$, and 28, the mobility score was determined on days 12 and 28 , and the histolopathology of the knee joint was examined on day 29.

\section{RESULTS}

Ethanol extract of Psidium guajava leaves significantly suppressed the swelling of the paws in chronic phase based on increasing of edema $(\%)$, while starting on day 20. EEPG at $250 \mathrm{mg} / \mathrm{kg}$ was most effective in significantly reducing arthritis scores $(p<0.05)$. Histopathological examination showed repair of the knee joint synovial membrane and cartilage.

\section{CONCLUSIONS}

Psidium guajava leaf extract is effective in decreasing the inflammatory response and arthritic symptoms in rats with adjuvant-induced arthritis. Psidium guajava leaves can be developed into an alternative anti-arthritis treatment.

Keywords: Psidium guajava, antiarthritis, edema, adjuvant induced arthritis, rats
*Department of Pharmacy, Faculty of Health Sciences, Jenderal Soedirman University, Purwokerto, Central Java, Indonesia

**Medical Faculty, Universitas Brawijaya, Malang, East Java, Indonesia

\section{Correspondence:}

Hanif Nasiatul Baroroh, M.Sc, Apt.

Department of Pharmacy,

Faculty of Health Sciences, Jenderal Soedirman University, Jl. Dr. Soeparno, Karangwangkal, Purwokerto, Central Java, Indonesia Email: h_baroroh@yahoo.co.id

Univ Med 2015;34:197-204 DOI: 10.18051/UnivMed.2016.v35.197-204 pISSN: 1907-3062 / eISSN: 2407-2230

This open access article is distributed under a Creative Commons Attribution-Non Commercial-Share Alike 4.0 International License 
Daun Psidium guajava menurunkan respon inflamasi dan gejala artritis pada tikus terinduksi adjuvant induced arthritis

\section{ABSTRAK}

\section{LATAR BELAKANG}

Daun jambu biji merupakan salah satu tanaman herbal yang telah terbukti sebagai antioksidan dan antiinflamasi. Penelitian ini bertujuan untuk menyelidiki aktivitas anti artritis dari efek ekstrak etanol daun Psidium guajava (EEPG) terhadap artritis yang terinduksi complete Freund Adjuvant (CFA) pada tikus.

\section{METODE}

Penelitian eksperimantal dilakukan pada 40 ekor tikus Sprague dewley wistar jantan. Mereka dibagi menjadi 5 kelompok dan tiap kelompok diinduksi dengan 0,2 $\mathrm{ml} \mathrm{CFA}(1 \mathrm{mg} / \mathrm{ml})$ pada hari ke-1 dan diberikan injeksi booster dengan 0,1 $\mathrm{ml}$ CFA $(1 \mathrm{mg} / \mathrm{ml})$ pada hari ke-5. Kelompok I sebagai control arthritis, II diberikan dexamethason (6,75 mg.kg-1 p.o.), kelompok III, IV dan V diberikan EEPG dengan dosis $250 \mathrm{mg} / \mathrm{kg} \mathrm{BB} \mathrm{(p.o),} 500 \mathrm{mg} / \mathrm{kg} \mathrm{BB} \mathrm{(p.o)}$ dan $750 \mathrm{mg} / \mathrm{kg} \mathrm{BB}$ (p.o) pada hari ke 14-28. Aktivitas antiarthritis diamati melalui skor artritis, lingkar kaki diamati pada hari ke $0,1,4,8,12,16,20,24$, dan 28, skor mobilitas diamati pada hari ke 12 dan 28 serta histopatologi sendi lutut diamati pada hari ke-29.

\section{HASIL}

Ekstrak etanol daun Psidium guajava mampu menurunkan pembengkakan secara signifikan mulai hari ke 20. EEPG dosis $250 \mathrm{mg} / \mathrm{kg}$ BB paling efektif dalam menurunkan skor artritis secara signifikan (p<0,05). Hasil histopatologi sendi lutut menunjukkan perbaikan pada membran sinovial dan kartilago.

\section{KESIMPULAN}

Ekstrak daun Psidium guajava efektif menurunkan respon inflamasi dan gejala artritis pada tikus yang terinduksi adjuvant induced arthritis. Daun jambu biji dapat dikembangkan menjadi terapi alternatif antiartritis.

Kata kunci : Psidium guajava, antiarthritis, edema, adjuvant induced arthritis, tikus

\section{INTRODUCTION}

Rheumatoid arthritis (RA) is an autoimmune disease that attacks the joints of the body and causes chronic inflammation in the synovium. Inflammation in RA joints is a very complex process and involves the interaction of a variety of inflammatory cells, autoantibodies and cytokines. ${ }^{(1)}$ Conventional treatments that have been used to overcome arthritis and inhibit the development of RA involve the disease modifying anti-rheumatic drugs (DMARDs). ${ }^{(2)}$ Traditional medicine using plant extracts continues to provide health coverage for over
$80 \%$ of the world's population, especially in the developing world. ${ }^{(3)}$ Recently, the use of plant extracts for arthritis treatment is being promoted in the USA, especially after the withdrawal of FDA-approved anti-inflammatory drugs. One of the plants that have the potential to be developed as an antiarthritic drug is the guava plant (Psidium guajava). Guava contains tannins, phenolic compounds, flavonoids, volatile oils, sesquiterpenes and triterpenoids. ${ }^{(4)}$ Flavonoids and phenolic compounds contained in guava have been proven to be antioxidant and antiinflammatory. ${ }^{(5)}$ Jahagirdar et al. ${ }^{(6)}$ reported that a hydroalcoholic extract of guava leaves at a dose 
of $200 \mathrm{mg} / \mathrm{kg} / \mathrm{day}$ showed antiarthritic activity. Dutta and Das ${ }^{(7)}$ observed that an ethanol extract of guava leaves at doses of $250 \mathrm{mg} / \mathrm{kg}$ and 500 $\mathrm{mg} / \mathrm{kg}$ body weight significantly inhibited chronic inflammation and reduced the arthritis index. Ojewole ${ }^{(8)}$ suggested that the aqueous extract of guava leaves in the dose range of 50$800 \mathrm{mg} / \mathrm{kg}$ administered intraperitoneally had analgesic and anti-inflammatory activity in rats with egg albumin-induced arthritis. The aqueous extract of guava leaves at doses of 125, 250, and $500 \mathrm{mg} / \mathrm{kg}$ had antiinflammatory activity and decreased edema in rats, with percentage inhibition of $40.81 \%, 55.45 \%$, and $43.61 \%$, respectively. ${ }^{(9)}$

The Freund's adjuvant model was chosen in this study, as it develops chronic swelling in multiple joints, with influence of inflammatory cells with erosion of joint cartilage and bone destruction. Freund's complete adjuvant-induced arthritis is a well established rat model and has been widely used for many years for evaluation of the anti-inflammatory and anti-arthritic potential of various agents..$^{(10,11)}$

Guava leaves has the potential to be developed as an antiarthritic drug. The present study aimed to evaluate the anti-arthritic activity of the ethanol extract of the leaves of Psidium guajava (EEPG) against complete Freund's adjuvant (CFA) induced arthritis in rats, especially with reference to its anti-inflammatory properties, using dexamethasone as reference drug.

\section{METHODS}

\section{Research design}

This study used a completely randomized design of undirectional pattern. Freund's adjuvant induced arthritis model was used to assess the anti-arthritic activity of the ethanolic extract of P.guajava in rats. The research was carried out in the Laboratory of Pharmaceutical Biology, Department of Pharmacy, Faculty of Medicine and Health Sciences, Universitas Jenderal Sudirman and the Laboratory of
Pathology and Anatomy, Medical Faculty, Gadjah Mada University, Yogyakarta. The study was conducted from Agustus 2013 to February 2014.

\section{Animals}

The study was conducted in male Sprague Dawley (SD) rats weighing 130-150 g obtained from the animal house in the Faculty of Pharmacy, Gadjah Mada University. Animals were acclimatized to experimental conditions in cages and kept under standard environmental conditions $\left(22 \pm 3^{\circ} \mathrm{C} ; 12 / 12 \mathrm{~h}\right.$ light/dark cycle). Rats were allowed to feed and water ad libitum.

\section{Plant material}

Leaves were collected from Karangwangkal, Purwokerto. Taxonomic identification of the plant was made by the Laboratory of Taxonomy, Faculty of Biology.

\section{Preparation of extract}

The powdered leaves $(1000 \mathrm{~g})$ were successively extracted with ethanol $\left(70-80^{\circ} \mathrm{C}\right)$ for $3 \times 24 \mathrm{~h}$. The macerate was then evaporated in a rotary evaporator for \pm 90 minutes in the temperature range of $70-80^{\circ} \mathrm{C}$, then evaporated over a water bath until a thick extract was produced, which was stored in the refrigerator until used in the study.

\section{Experimental animals}

Animals were randomly divided into five groups $(n=8)$. The sample size determination was based on Federer's formula and the randomization of the test animals in this research used a completely randomized design (CRD) of unidirectional pattern. Group I receiving $1 \mathrm{mg}$ / $\mathrm{mL}$ complete Freund's adjuvant (CFA) served as an arthritic control, group II receiving dexamethasone (6.75 mg.kg-1 p.o.) served as the reference standard, while group III, IV and V received ethanolic extract at doses of $250 \mathrm{mg} / \mathrm{kg}$ BW (p.o), $500 \mathrm{mg} / \mathrm{kg} \mathrm{BW} \mathrm{(p.o)} \mathrm{and} 750 \mathrm{mg} / \mathrm{kg}$ BW (p.o), respectively. Each group was induced by $0.2 \mathrm{mLCFA}(1 \mathrm{mg} / \mathrm{mL})$ on day 1 and received 
a booster injection of $0.1 \mathrm{~mL} \mathrm{CFA}(1 \mathrm{mg} / \mathrm{mL})$ on day 5. To assess the anti-arthritic activity of $P$. gujava, the extracts were given on days 1428.

\section{Evaluation of arthritic score}

Each paw was scored on a scale of $0-4$ for the degree of swelling, erythema and deformity (maximum score 16 per animal) as follows: $0=$ normal, $1=$ slight erythema and/or swelling of the ankle or wrist, $2=$ moderate erythema and/ or swelling of ankle or wrist, $3=$ severe erythema and/or swelling of ankle or wrist and $4=$ complete erythema and swelling of toes or fingers and ankle or wrist and inability to bend the ankle or wrist. ${ }^{(12)}$ The arthritic score was measured on days $0,1,4,8,12,16,20,24$, and 28.

\section{Evaluation of mobility score}

Whole animal mobility was scored between 0 and 4 according to the following definitions: 0 = normal, 1 = slightly impaired, 2 = major impairment, $3=$ does not step on paw, and $4=$ no movement. The mobility score was measured on days 12 and 28 .

\section{Evaluation of paw edema}

The paw edema was measured on days 0 , $1,4,8,12,16,20,24$, and 28 . The mean changes in injected paw edema with respect to initial paw volume, were calculated on respective days and the percentage of inhibition of paw edema with respect to the untreated group was calculated on respective days by the following formula: ${ }^{(13)}$

Increasing of edema $(\%)=\left[\frac{\mathrm{Vt}-\mathrm{Vo}}{\mathrm{Vo}}\right] \times 100 \%$

$\mathrm{Vt}=$ Paw edema on day $\mathrm{t}$

Vo $=$ Paw edema on day 0

\section{Histological processing and assessment of arthritic damage}

Rats were killed by ether anesthesia. Knee joints were removed and fixed for 4 days in $10 \%$ formalin. After that the specimens were processed for preparation of paraffin-embedded tissue sections (7 ìm thick), which were stained with hematoxylin and eosin.

\section{Statistical analysis}

The data were expressed and analyzed using SPSS software. Statistical analysis of difference between groups was evaluated by one-way ANOVA followed by LSD test. The value of $p<0.05$ was regarded as statistically significant.

\section{Ethical clearance}

This study was accorded ethical clearance by the Commision on Research Ethics in Medicine and Health Sciences, Faculty of Medicine, Universitas Jenderal Soedirman.

\section{RESULTS}

Injection of CFA increased edema, with a peak increase of $29.46 \% \pm 5.58$ on day 12 following the injection of CFA in the arthritic control group (Table 1). Over the 28-day study, rats treated with extract at doses of 250,500 and $750 \mathrm{mg} / \mathrm{kg}$ showed a significant decrease in edema ( $\mathrm{p}<0.05)$ starting on day 20 up to day 28 , as compared to control rats (Figure 1). Dexamethasone, the standard anti-arthritic drug, also showed a significant decrease in edema.

There was an increase in arthritic scores after induction with CFA that indicated systemic inflammation due to the arthritic condition (Figure 1). In the arthritic control group, the arthritis scores remained at their peak level from day 8 to day 24, and started to decrease on day 28. Following the CFA injections, the rats developed arthritis beginning on day 4 and reached a peak level on day 8 . Rats treated with dexamethasone and P.guajava leaf extract showed a significant decrease in arthritis score.

Throughout the 28-day study, all arthritis groups showed a decrease in mobility scores that was statistically not significant (Table 2). Rats treated with $P$. guajava extract with the dose of $250 \mathrm{mg} / \mathrm{kg}$ showed the greatest decrease in mobility scores. 
Table 1. The increasing of edema (\%) in the control and treated animals groups with P.guajava extracts on freund's adjuvant complete induced arthritis

\begin{tabular}{|c|c|c|c|c|c|c|}
\hline \multirow{2}{*}{$\begin{array}{l}\text { Day after } \\
\text { adjuvant } \\
\text { induction }\end{array}$} & \multicolumn{5}{|c|}{$\begin{array}{c}\text { Incre asing of edema (\%) } \\
(m e a n \pm \mathrm{SEM})\end{array}$} & \multirow[b]{2}{*}{$\mathbf{p}$} \\
\hline & $\begin{array}{r}\text { Control } \\
\text { arthritis }\end{array}$ & $\begin{array}{c}\text { Standard drug } \\
\text { (Dexamethasone) }\end{array}$ & $\begin{array}{l}\text { P. guajava } \\
250 \mathrm{mg} / \mathrm{kg}\end{array}$ & $\begin{array}{l}P . g u g i a v a \\
500 \mathrm{mg} / \mathrm{kg}\end{array}$ & $\begin{array}{l}\text { P. gugiava } \\
750 \mathrm{mg} / \mathrm{kg}\end{array}$ & \\
\hline 0 & $7.81 \pm 4.41$ & $2.36 \pm 0.05$ & $2.35 \pm 0.05$ & $2.36 \pm 0.05$ & $2.35 \pm 0.05$ & 0.840 \\
\hline 4 & $7.81 \pm 4.41$ & $12.14 \pm 2.82$ & $14.90 \pm 3.84$ & $8.99 \pm 4.31$ & $8.08 \pm 3.21$ & 0.627 \\
\hline 8 & $21.13 \pm 5.7$ & $13.77 \pm 2.44$ & $17.01 \pm 3.72$ & $15.81 \pm 5.09$ & $15.42 \pm 3.10$ & 0.781 \\
\hline 12 & $29.46 \pm 5.58$ & $14.81 \pm 2.58$ & $17.01 \pm 1055$ & $17.44 \pm 5.60$ & $15.42 \pm 4.27$ & 0.175 \\
\hline 16 & $16.33 \pm 3.90$ & $8.51 \pm 3.94$ & $14.95 \pm 2.72$ & $13.29 \pm 3.07$ & $13.95 \pm 3.77$ & 0.592 \\
\hline 20 & $17.39 \pm 4.90^{\circ}$ & $4.78 \pm 1.50^{\wedge}$ & $4.82 \pm 1.36 \mathrm{a}$ & $8.02 \pm 2.78^{\star}$ & $14.99 \pm 3.94^{6}$ & 0.020 \\
\hline 24 & $20.58 \pm 5.68^{b}$ & $2.49 \pm 1.16^{a}$ & $6.97 \pm 1.83^{n}$ & $7.99 \pm 2.62^{\wedge}$ & $11.80 \pm 4.02^{b}$ & 0.009 \\
\hline 28 & $17.39 \pm 3.76^{b}$ & $163 \pm 1.60^{\star}$ & $5.37 \pm 1.96^{A}$ & $7.99 \pm 2.74^{x}$ & $11.25 \pm 4.11^{b}$ & 0.009 \\
\hline
\end{tabular}

Values expressed in average \pm SEM of 8 rats; $a=$ significance at the level of $p<0.05$ compared by control arthritis; $b=$ significance at the level of $\mathrm{p}<0.05$ compared by standard drug

Histopathologically, after treatment with dexamethasone (Figure 2B), there was a reduction in the inflammatory condition of the synovial membranes, accompanied by cartilage repair, compared to the arthritis in the knee joints of the controls. The group treated with guava leaf extract at the dose of $250 \mathrm{mg} / \mathrm{kg}$
(Figure 2C) also showed a reduction in the inflammatory condition of the synovial membranes, accompanied by cartilage repair, while treatment with guava leaf extract at the doses of $500 \mathrm{mg} / \mathrm{kg}$ (Figure 2D) and $750 \mathrm{mg} /$ $\mathrm{kg}$ (Figure 2E) showed repair of the synovial membranes.

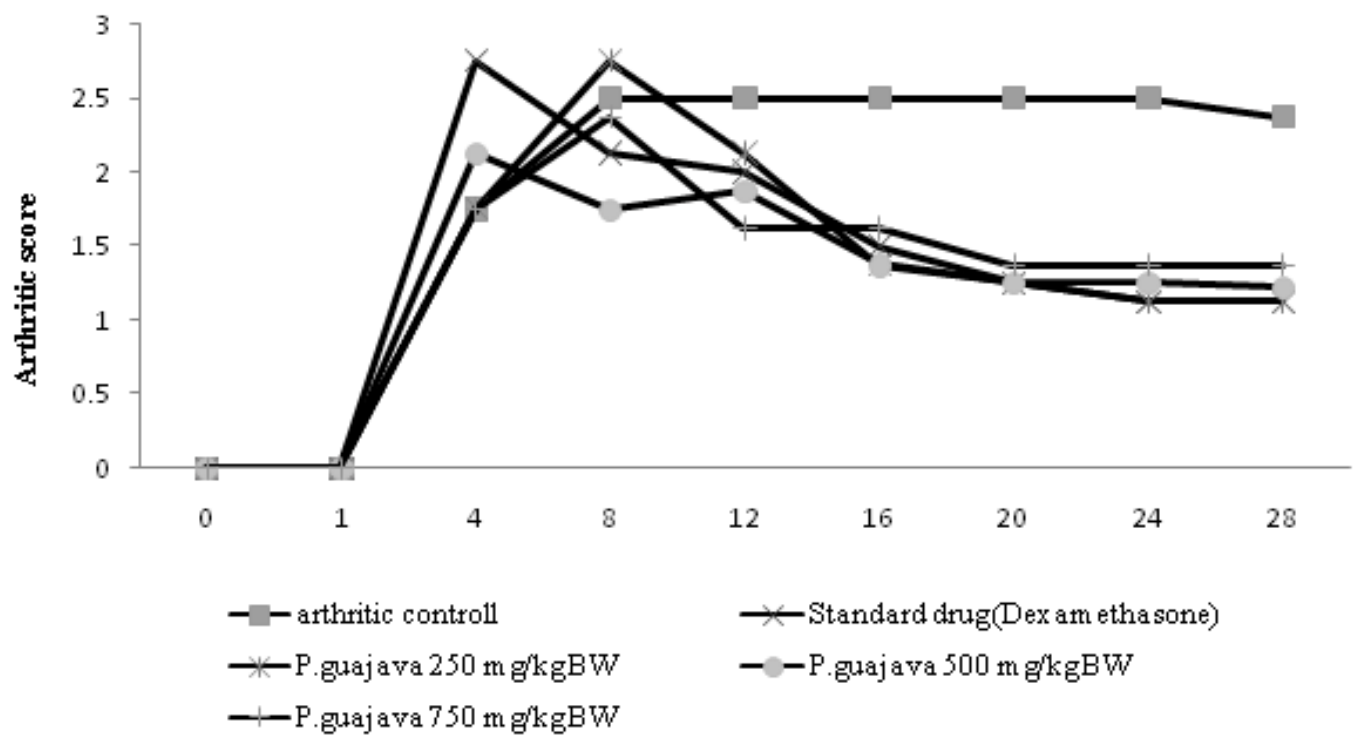

Figure 1. Arthritis scores in control and experimental groups. As a result of inflammation induced by complete Freund's adjuvant, the arthritis scores were increased $(\mathrm{p}<0.05)$ in treated rats when compared with control rats. Treatment with dexamethasone and Psidium guajava showed significantly decreased $(\mathrm{p}<0.05)$ arthritis scores beginning on day 20 
Table 2. Distribution of mean of mobility score by treatment groups after $12^{\text {th }}$ and $28^{\text {th }}$ day on freund's adjuvant complete induced arthritis

\begin{tabular}{|c|c|c|c|c|c|c|}
\hline \multirow{2}{*}{$\begin{array}{l}\text { Day after } \\
\text { adjuwant } \\
\text { induction }\end{array}$} & \multicolumn{5}{|c|}{ Treatment group } & \multirow[b]{2}{*}{$\mathbf{p}$} \\
\hline & $\begin{array}{c}\text { Arth ritic } \\
\text { control }\end{array}$ & $\begin{array}{c}\text { Stand ard } \\
\text { drug }\end{array}$ & $\begin{array}{r}P . g u g i a v a \\
250 \mathrm{mg} / \mathrm{kg}\end{array}$ & $\begin{array}{l}P . g u g i a v a \\
500 \mathrm{mg} / \mathrm{kg}\end{array}$ & $\begin{array}{l}P . g u a j a v a \\
750 \mathrm{mg} / \mathrm{kg}\end{array}$ & \\
\hline $12^{\text {zl }}$ day & $1.75 \pm 0.16$ & $1.37 \pm 0.18$ & $1.51 \pm 0.19$ & $1.37 \pm 0.18$ & $1.37 \pm 0.18$ & 0.524 \\
\hline $28^{\text {th }}$ day & $1.62 \pm 0.18$ & $1.12 \pm 0.12$ & $1.12 \pm 0.12$ & $1.25 \pm 0.16$ & $1.125 \pm 0.12$ & 0.091 \\
\hline
\end{tabular}

Values of mobility score expressed in average \pm S.E.M of 8 rats
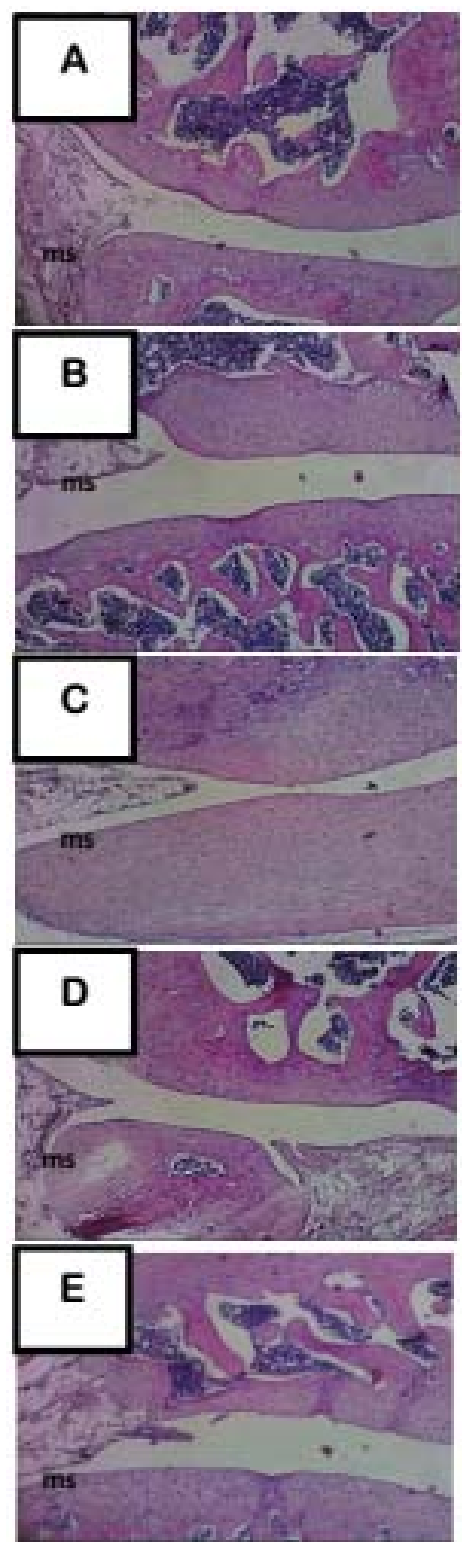
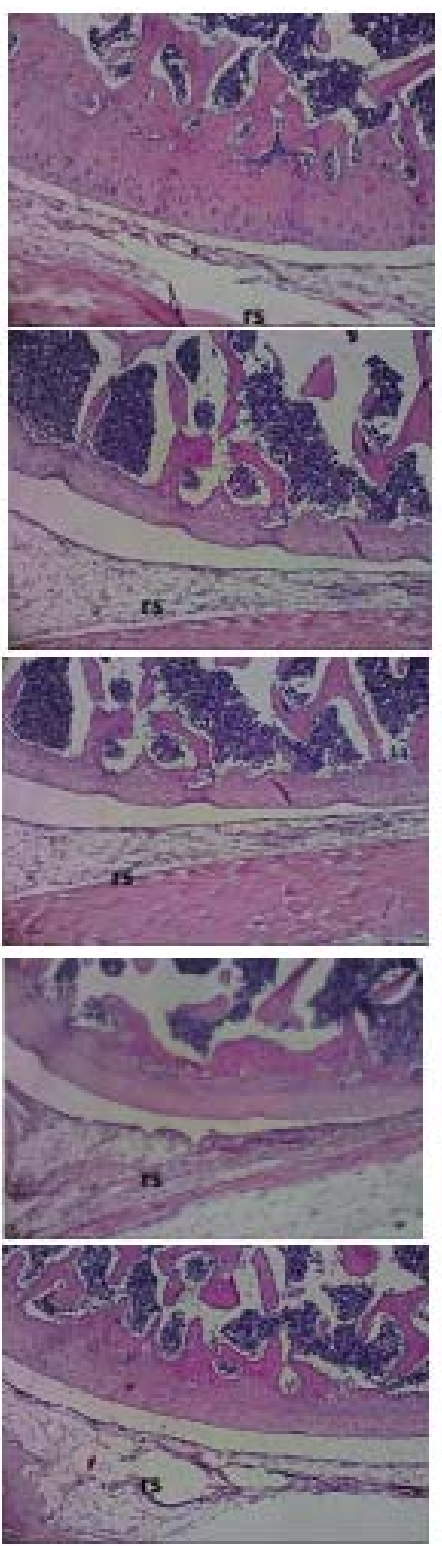
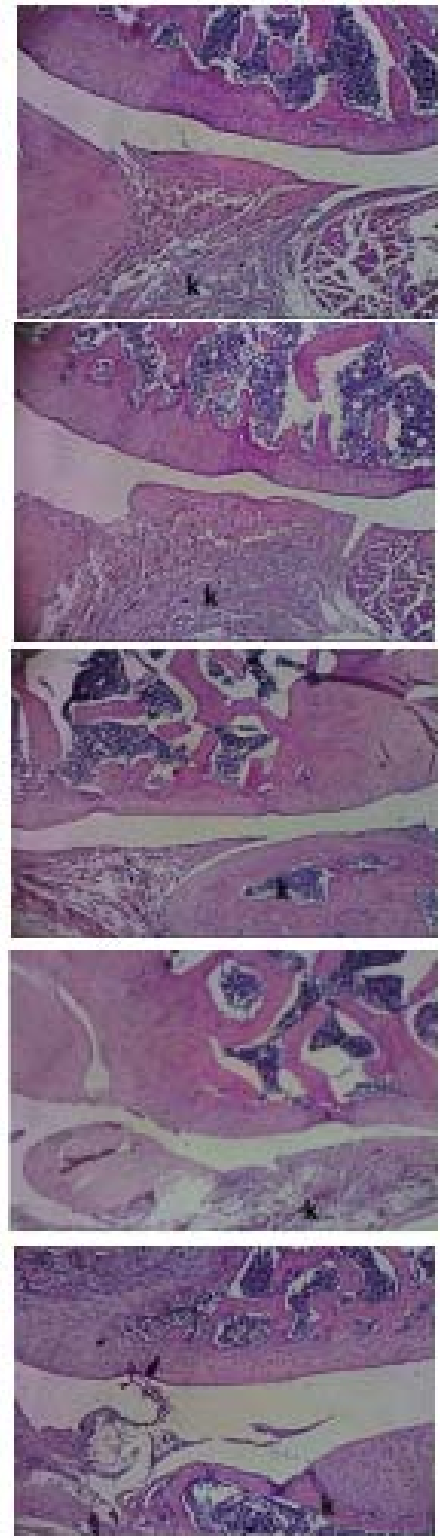

Figure 2. Histopathology of rat knee joint tissues; A (arthritic rat): inflammation of the synovial membrane and cartilage destruction; $\mathrm{B}$ (rat on dexamethasone): reduction of synovial membrane inflammation and cartilage repair; C (rat on EEPG $250 \mathrm{mg} / \mathrm{kgBB}$ ): reduction of synovial membrane inflammation and cartilage repair; D (rat on EEPG $500 \mathrm{mg} / \mathrm{kg}$ ): synovial membrane repair; E (rat on EEPG $750 \mathrm{mg} / \mathrm{kgBB}$ ): synovial membrane repair. HE staining, magnification 40x. Synovial membrane (ms), joint cavity (rs), cartilage $(\mathrm{k})$ 


\section{DISCUSSION}

The present study was carried out to evaluate the effect of $P$. guajava leaf extract in inflammatory disease. The Freund's adjuvant model was chosen as it induces chronic swelling in multiple joints, with influence of inflammatory cells with erosion of joint cartilage and bone destruction. Freund's complete adjuvant-induced arthritis is a well established rat model and has been widely used from many years for evaluation of the anti-inflammatory and anti-arthritic potential of various agents. ${ }^{(14,15)}$ Nagakura et al. ${ }^{(10)}$ reported that the induction of arthritis in the Freund's adjuvant model in rats caused joint inflammation, inflammatory cell infiltration, and cartilage and bone destruction. Freund's adjuvant contains Mycobacterium tuberculosis H37Ra or Mycobacterium butyricum, which release endotoxins that trigger the production of nitric oxide (NO). ${ }^{(16)}$ NK cells, mast cells, eosinophils, neutrophils, cells and tissues dendritic endothelium are important sources of NO production associated with the immune response, because the activation of macrophages results in the production of several cytokines, including IL 1 , IL 6, interferon $\gamma$ (IFN $\gamma$ ) and TNF $\alpha$, which have been implicated in immune arthritis. ${ }^{(17)}$ Various inflammatory mediators including cytokines (IL$1 \mathrm{~B}$ and TNF- $\alpha$ ), MCSF, interferons, and platelet derived growth factor (PDGF) are responsible for the swelling joints, bone deformations, and disability of joint function. ${ }^{(1)}$

The progress of the arthritic condition was evident around day 12, indicating systemic inflammation. ${ }^{(18)}$ The swelling was found to be increasing in the initial phase of inflammation and becoming constant within 2 weeks (beginning on day 4). These increases in arthritic and mobility scores were found to be associated with chronic inflamation. Psidium guajava extract at doses of $250 \mathrm{mg} / \mathrm{kg}, 500 \mathrm{mg} / \mathrm{kg}$ and $750 \mathrm{mg} / \mathrm{kg}$ significantly suppressed the swelling of the paws in chronic inflammation over day 28 . The $P$. guajava leaf extract was found to be effective in decreasing arthritic scores, mobility scores, and inflammatory responses.

Several studies have shown the antioxidant and anti-inflammatory properties of flavonoids. Porwal et al. ${ }^{(4)}$ reported that $P$. guajava leaf extract contained essential oils, flavonoids, triterpenoids, vitamin C, tannins, and phenolics. Although the actual mechanism of suppression of the arthritic condition is not known, it can be correlated with the presence of flavonoids in suppressing the inflammation and antioxidant activity. Quercetin in P. guajava suppressed and inhibited nitric oxyde (NO) production, catalyzed by inducible nitric oxide synthase (iNOS). ${ }^{(19)}$ Chen et al. ${ }^{(20)}$ reported that quercetin had antioxidant activity by suppressing the NF- $\kappa \mathrm{B}$ signaling pathway. Quercetin-3-Oglucopyranoside and morin in $P$. guajava leaves have antioxidant activity. ${ }^{(21)}$ Vyas et al. ${ }^{(22)}$ reported that $P$. guajava had antioxidant activity and may have the potential to be developed as an anti-inflammatory drug. In a previous study, aqueous extract of P.guajava leaves at a dose of $250 \mathrm{mg} / \mathrm{ml}$ had anti-inflammatory activity in male albino rats with arthritis induced by carrageenan. ${ }^{(9)}$ From the results observed in the current investigation, it may be concluded that $P$. guajava leaves have a potentially in vivo antiarthritic activity, and warrants more in-depth investigations on the mechanism of action of its anti-arthritic activity. In practice, it can be developed as an alternative anti-arthritis drug. It is suggested that $P$. guajava leaves may be useful in the teratment of the arthritic condition in rheumatoid arthritis. One limitation of this study was indicated by the animal ethical clearance. The study would have provided better conclusions if validated with a larger sample size.

\section{CONCLUSION}

Psidium guajava leaf extract is found to be effective in decreasing the inflammatory response and arthritic symptoms in adjuvant-induced arthritic rats. 


\section{CONFLICT OF INTEREST}

All authors declare that there was no actual or potential conflict of interest.

\section{ACKNOWLEDGEMENT}

The authors thank Universitas Jenderal Soedirman for financial support and Gadjah Mada University for providing necessary facilities to carry out the research work.

\section{REFERENCES}

1. Mclnnes IB, Schett G. The pathogenesis of rheumatoid arthritis. N Engl J Med 2011;365: 2205-19.

2. National Collaborating Centre for Chronic Conditions. Rheumatoid arthritis: national clinical guideline for management and treatment in adults. London: Royal College of Physicians; 2009.

3. World Health Organization. Traditional medicine: growing needs and potential. Geneva: World Health Organization Policy Perspectives on Medicines; 2002.

4. Porwal V, Singh P, Gurjar D. A Comprehensive study on different methods of extraction from guava leaves for curing various health problem. IJERA 2012;2:490-6.

5. Barbalho SM, Machado FMV, Goulart RDA et al. Psidium guajava: A plant of multipurpose medicinal applications. Met Aromat Plant 2012; 4:1-6.

6. Jahagirdar K, Ghosh P, Adil SM, et al. Effect of hydroalcoholic extract of Psidium guyava Linn. on complete Freund's adjuvant induced arthritis in laboratory animals. Pharmacologyonline 2010;3:706-19.

7. Dutta S, Das S. A study of the anti-inflamatory effect of the leaves of Psidium guajava Linn. on experimental animal models. Pharmacognosy Res 2010;2:313-7.

8. Ojewole JA. Antiinflammatory and analgesic effects of Psidium guajava Linn. (Myrtaceae) aqueous extract in rats and mice. Methods Find Exp Clin Pharmacol 2006;28:441-6.

9. Weni L, Harliansyah, Widayanti. Antiinflammatory activity of the extract of guava leaves (Psidium guajava L) in the rat (Rattus norvegicus L). IJCC 2011;2:169-72.

10. Nagakura Y, Okada M, Kohara A, et al. Allodynia and hyperalgesia in adjuvant induced arthritis rats: time course of progression and efficacy of analgesics. J Pharmacol Exp Ther 2003;306:490-7.

11. Bevaart L, Vervoordeldonk MJ, Tak PP. Evaluation of therapeutic in animal models of arthritis, how does it relate to rheumatoid arthritis? Review arthritis and rheumatism. Arthritis Rheum 2010;62:2192-205.

12. Brand DD, Latham KA, Rosloniec EF. Collageninduced arthritis. Nature Protocols 2007;2:126975.

13. Panchal AH, Patel RK, Bhandari A. Antiarthritic and synergetic activity of Wedelia calendulacea $\mathrm{L}$. with methotrexate in adjuvant induced arthtitis with cardioprotective activity in rat. Pharmacologyonline 2012;3:175-87.

14. Patil MVK, Kandhare AD, Bhise SD. Antiarthritic and anti-inflammtory activity of Xanthium strumarium L. ethanolic extract in Freund's complete adjuvant induced arthritis. Biomed Aging Pathol 2012;2:6-15.

15. Snekhalatha U, Anburajan M, Venkatraman B, et al. Evaluation of complete Freund's adjuvantinduced arthritis in a Wistar rat model, comparison of thermography and histopathology. Rheumatol 2012;72:375-82.

16. Stills HF. Adjuvants and antibody production: dispelling the myths associated with Freund's complete and other adjuvants. ILAR Journal 2005;46:280-93.

17. Ibiza $\mathrm{S}$. The role of nitric oxide in the regulation of adaptive immune responses. CNIC 2008;2: 103-7.

18. Venkatesha SH, Rajaiah R, Berman BM, et al. Immunomodulation of autoimmune arthrits by herbal CAM. Evid Based Complement Alternat Med 2011:986797.

19. Florez M, Gutirez B, Sanchez S. Quercetin attenuates nuclear factor-B activation and nitric oxide production in interleukin-1 activated rat hepatocytes. J Nutr 2005; 135:1359-65.

20. Chen JC, Ho FM, Chao PD, et al. Inhibition of iNOS gene expression by quercetin is mediated by the inhibition of IêB kinase, nuclear factorkappa B and STAT1, and depends on heme oxygenase-1 induction in mouse BV-2 microglia. Eur J Pharmacol 2005;521:9-20.

21. Tachakittirungrod S, Ikegami F, Okonogi S. Antioxidant active principles isolated from Psidium guajava grown in Thailand. Sci Pharm 2007;75:179-93.

22. Vyas N, Tailang M, Gavatia NP. Antioxidant potential of Psidium guajava Linn. Intern J Pharm Tech Res 2010;2:417-9. 